\title{
Sutter Buttes-The Lone Volcano in California's Great Valley
}

he volcanic spires of the Sutter
Buttes tower 2,000 feet above
the farms and fields of California's
Great Valley, just 50 miles north-
northwest of Sacramento and 11
miles northwest of Yuba City. The
only volcano within the valley, the
Buttes consist of a central core of
volcanic domes surrounded by a
large apron of fragmental volcanic
debris. Eruptions at the Sutter Buttes
occurred in early Pleistocene time,
1.6 to 1.4 million years ago. The
Sutter Buttes are not part of the
Cascade Range of volcanoes to the
north, but instead are related to the
volcanoes in the Coast Ranges to the
west in the vicinity of Clear Lake,
Napa Valley, and Sonoma Valley.

In the fall of 1841 an overland party from the United States Exploring Expedition led by Charles Wilkes traveled down the valley of the Sacramento River in central California, rejoining the expedition's ships later in San Francisco. The geologist of the expedition, James Dwight Dana, could not help noticing in the middle of that broad, flat valley an isolated cluster of hills that tower 2,000 feet above the valley floor "like an island in a vast prairie of millpond smoothness" (Dana, 1849). Dana

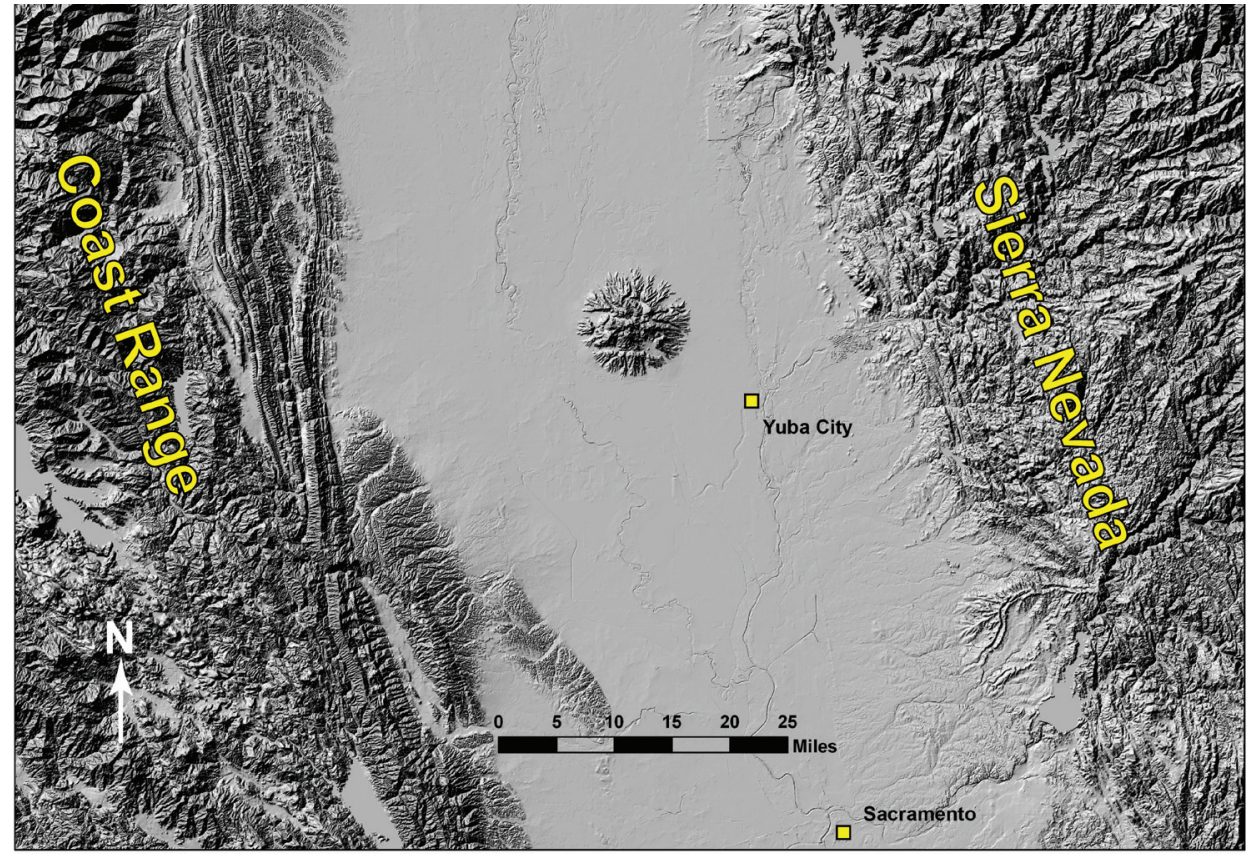

Rising 2,000 feet from the center of California's flat Sacramento Valley near Yuba City, the isolated Sutter Buttes were formed by volcanism more than 1 million years ago. Their dramatic isolation is well shown in this shadedrelief image. Base map from U.S. Geological Survey elevation data.

explored the hills, now known as the Sutter Buttes, on October 16. He recognized them as the remains of an extinct volcano and described the various volcanic rocks found in them, becoming the first geologist to study this distinctive geologic and geographic feature of the valley. Dana also commented, "The whole country, we were told, was flooded during the winter fresh-

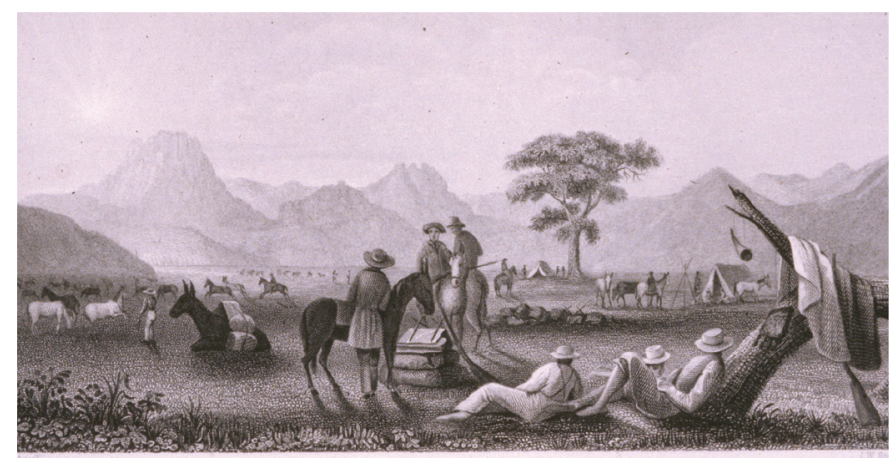

In 1841, an overland party from the United States Exploring Expedition led by Charles Wilkes explored the Sutter Buttes, camping southeast of South Butte, as shown in this lithograph. Engraved by J. W. Steel from a drawing by Alfred T. Agate, an artist with the expedition. ets, and the deer and antelope of the plains then take to the Bute hills."

In the 170 years since the Wilkes Expedition, few other geologists have investigated the Sutter Buttes and the surrounding area. In 1929 Howel Williams, a Professor at the University of California at Berkeley, named the major landscape features and correctly outlined the basic geologic history (Williams, 1929). Nearly 50 years later, Williams and his Berkeley colleague, Garniss Curtis, revised and elaborated the volcanic history, aided greatly by radiometric dating of rocks (Williams and Curtis, 1977). In addition, the petroleum industry carried out investigations of sedimentary rocks adjacent to the Sutter Buttes and drilled many deep wells in search of natural gas. Although these investigations have determined the general history of Sutter Buttes, some aspects remain uncertain and are the subject of ongoing investigations. 


\section{Regional Geology and Anatomy of the Volcano}

For much of the past 75 million years, the area of the Great Valley of California was a shallow sea that connected to the Pacific Ocean. Rivers carried sediments from the Sierra Nevada and Klamath Mountains and deposited them in this sea. Over time, these sediments were compacted to form an enormous thickness of marine shale and sandstone. The region eventually rose to just above sea level as an immense river valley, dominated by the Sacramento, Feather, and San Joaquin Rivers. Before the volcanic eruptions that formed the Sutter Buttes, the area was a uniform, flat plain on which rivers meandered back and forth, depositing sand, gravel, and mud on top of the earlier marine sediments.

The Sutter Buttes as we see them today consist of three major parts, termed by Professor Williams the "castellated core," the "moat," and the "rampart." The castellated core comprises

\section{Geologic Map of the Sutter Buttes Volcano}

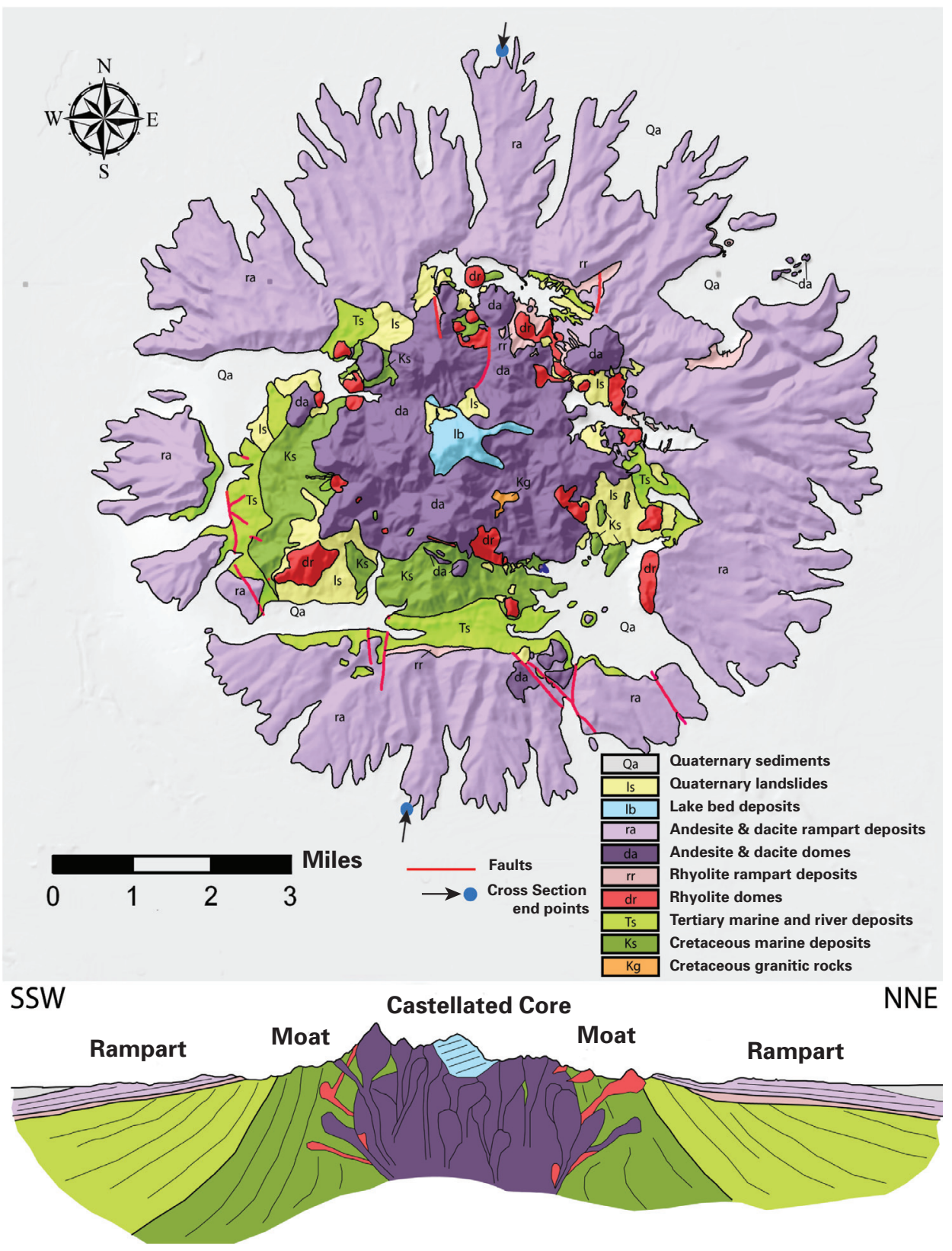

Geologic map and diagrammatic cross section of the Sutter Buttes. Geology compiled from Williams and Curtis (1977), Thamer (1961), and new mapping by Brian Hausback. The cross section is vertically exaggerated $3 \mathrm{X}$ to emphasize the topography.

\section{ACCESS TO SUTTER BUTTES}

The Sutter Buttes are mostly in private ranches owned by families that have held title to the lands since the early 1900's. In order to enter these lands for hiking and other activities, nonresidents must arrange access through groups such as the Middle Mountain Foundation

(http://www.middlemountain.org).

the high, craggy peaks in the center of the Sutter Buttes. These were formed by batches of partly molten rock (magma) that rose to the surface as viscous plugs, forming steep-sided volcanic features known as "domes." The domes originally looked much like the Chaos Crags in Lassen Volcanic National Park. The fragmented surface materials of the Sutter Buttes domes have now been eroded away, exposing their resistant interior parts.

Immediately surrounding the castellated core is the moat. This low-lying ring of valleys is underlain by sedimentary rocks older than the Sutter Buttes volcano. These include layers of shale, sandstone, and conglomerate that range in age from late Cretaceous ( $\sim 70$ million years ago) to just before the Sutter Buttes first erupted about 1.6 million years ago. The sedimentary layers of the moat have been uplifted and steeply tilted by the intruding volcanic domes of the castellated core, and the soft, weak shales and sandstones have eroded away over time to form the moat valleys.

The outermost part of the Sutter Buttes is the rampart, a broad area of low, outwardsloping hills that were formed by flows of fragmental volcanic debris that moved radially outward from their source in the castellated core. Some of this material resulted from hot, explosive eruptions like most of the eruptions of Mount St. Helens, whereas other material was sloughed off the cooler outer parts of the domes and highland slopes of the castellated core and deposited as debris flows.

\section{Volcanic History of the Sutter Buttes}

The first eruptions at Sutter Buttes occurred about 1.6 million years ago, in the early Pleistocene, when magma pushed upward through the thick pile of Sacramento Valley sediments. Some of the magma breached the surface to form extrusive domes in the rocky core of the Buttes. Explosive eruptions pulverized the extruding magma, depositing blocky fragments and volcanic ash that hardened into pyroclastic ("fire-broken") rocks. 
The first lavas to erupt were light-colored, often white, rhyolites - rocks rich in silica $\left(\mathrm{SiO}_{2}\right)$ and alkalis (potassium and sodium) but poor in magnesium and iron. The extruding lavas were so viscous that they accumulated at the surface as thick, pasty blobs, or lava domes. After about 30,000 years, these rhyolites were followed by more voluminous eruptions of andesite and dacite, lavas lower in silica and higher in magnesium and iron than the earlier rhyolites. Forming much larger domes, the andesites and dacites are darker in color than the rhyolite, typically medium to dark gray, contain abundant large crystals, and are commonly oxidized (rusted) to brick red.

The andesite-dacites erupted through numerous vents distributed throughout the castellated core. In addition to the magma that erupted at the surface, much andesite-dacite magma lodged below the ground as intrusive bodies, spreading and lifting the preexisting sedimentary layers. In this way, originally horizontal sedimentary layers around the perimeter of the volcano were bent upward to vertical and in some places overturned. This deformation is best displayed in the south moat of the volcano (see cross-section and map).

The eruption of voluminous andesite-dacite continued until about 1.4 million years ago, creating the mountainous interior of the Sutter Buttes. Eruptions of volcanic domes were

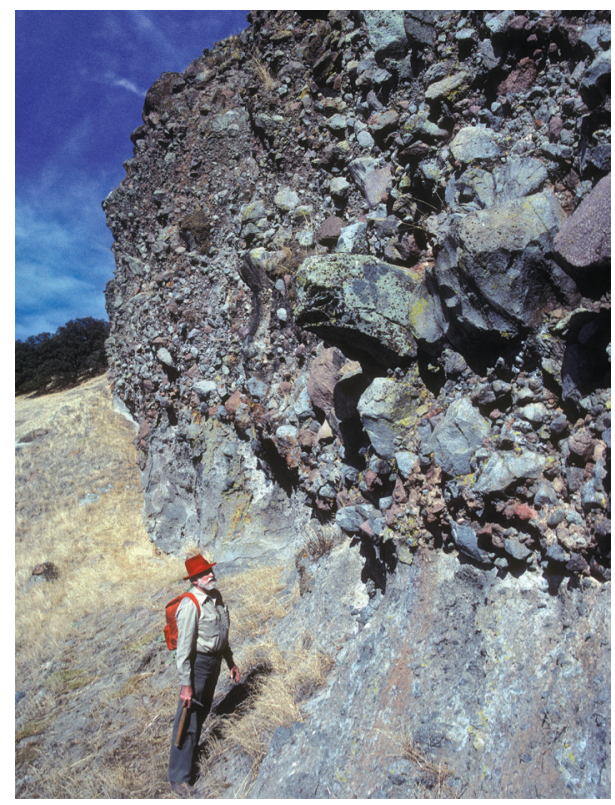

The sloping outer "rampart" of the Sutter Buttes was built by both volcanic mudflows (lahars) and hot flows of volcanic material (pyroclastic flows) that included large blocks, pictured here with a geologist (U.S. Geological Survey retired volcanolgist Robert L. Smith) for scale.

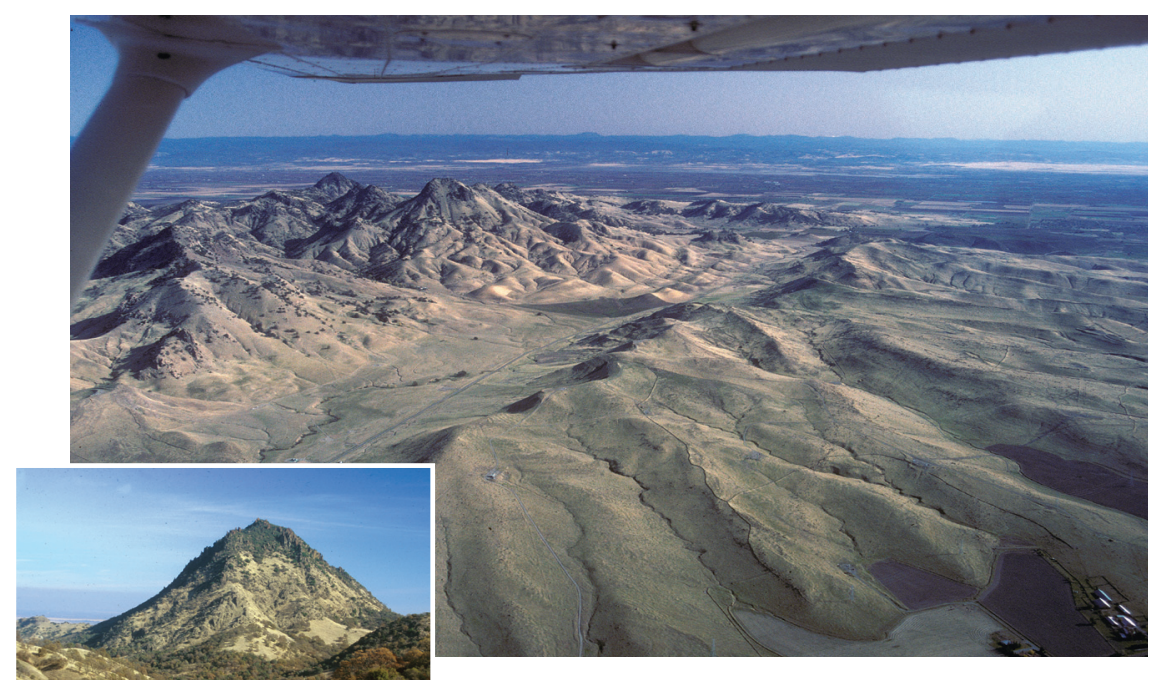

This aerial view looking east shows the low-lying "moat" between the high volcanic core of the Sutter Buttes and the sloping apron of the "rampart." The moat was formed by erosion

of soft sedimentary layers pushed up and tilted by the volcanic intrusions. Inset photograph at left shows North Butte, a high and well-preserved dacite dome in the central "castellated core" of the Sutter Buttes.

at times explosive because of an abundance of gases (mostly water vapor, carbon dioxide, and sulfur gases) in the magmas. The explosive eruptions fractured the dome rocks into fragments ranging from fine ash to giant blocks. These pyroclastic materials were carried downslope from the domes as slurries of debris made fluid by either hot volcanic gases (pyroclastic flows) or liquid water (lahars).

The very hot pyroclastic flows and the cooler lahars accumulated around the base of the castellated core in layer after layer of debris, forming the gently outward-sloping rampart, a continuous debris apron or "fan" all the way around the castellated core of volcanic domes and over the truncated top of the surrounding moat sediments.

The lowermost, rhyolitic layers of the rampart are exposed in only a few areas on the outer part of the moat valleys. These rhyolitic pyroclastic deposits are overlain by thick deposits derived from andesitic-dacitic pyroclastic flows and lahars. The uppermost layers of the rampart contain the largest blocks (about 30 feet in diameter), derived from the youngest, tallest, and best preserved domes of the core (South, North, West, Williams, Curtis, and Twin Peaks).

\section{Lakebeds}

In the very center of the castellated core are the remnant deposits of a very deep lake that was formed during the volcanic eruptions of the Sutter Buttes. These layered deposits are mostly sands and gravels of andesite-dacite composition and are at least 1,000 feet thick.
The lake may simply have filled a basin confined by volcanic domes, or the lake basin may have been excavated by powerful explosions during the andesite-dacite eruptive period. Today the lakebeds are surrounded and truncated by andesite-dacite domes that intruded into the layers and gently deformed and uplifted them to form a high central ridge in the Buttes.

\section{Today's Topography}

At the end of volcanism about 1.4 million years ago, the castellated core and the rampart looked much as they do today. The castellated core was dominated by the youngest, tallest andesite-dacite domes. The rampart was a thick accumulation of pyroclastic-flow and lahar deposits. Over the past 1.4 million years, however, the erosional effects of rain, running water, and wind have cut down into the softest and weakest of the geologic materials of the Buttes. Streams and landslides have preferentially cut into the relatively weak shale and sandstone sedimentary layers to carve the moat valleys. Outward-flowing streams have also cut down through the pyroclastic debris layers to form distinctive radial valleys in the rampart. However, the elevations of the hard volcanic domes have probably not been lowered much by erosion.

\section{How Did the Buttes Get There?}

An important question is whether the Sutter Buttes are related to the Cascade Range, which extends from the volcanoes of southern British Columbia to Lassen Peak in northern California, or to the Coast Range volcanic 


\section{NATURAL GAS IN THE SUTTER BUTTES}

For thousands of years, natural gas (largely methane) has leaked to the surface within and around the Sutter Buttes. Sometimes wildfires ignited these gas seeps, causing them to produce eerie blue flames that emerged from cracks in the ground and continued to burn long after the wildfires were quenched by rain. This phenomenon undoubtedly provoked a sense of awe and reverence for these dramatic crags located in the middle of a broad, flat valley. The native Maidu people named the Buttes "Histum Yani" or Middle Mountain.

Unlike the San Joaquin Valley (the southern part of California's Great Valley), the Sacramento Valley to the north has no appreciable deposits of oil, but it does have much natural gas. This gas was generated from microscopic plankton that died and sank to the ancient sea floor to be entombed in marine mud. Gradual burial by as much as 38,000 feet of overlying sediments created high temperatures and pressures that transformed the organic remains into gas. The volcanic upheaval that formed the Sutter Buttes pushed some of these sediments upwards, creating natural traps for methane and other gases rising from depth.

Exploration for gas in the Sutter Buttes area began in 1864, when a local worker and entrepreneur, Dexter Cook, sank a shaft near South Butte. The 30-foot-deep shaft filled with gas and inevitably exploded when he lit a candle at the bottom, injuring four men. The shaft was deepened to 65 feet and then sealed, leaving a pipe extending above the surface. The gas streamed out and for years produced a 5 -foot-tall, blue, smokeless flame.

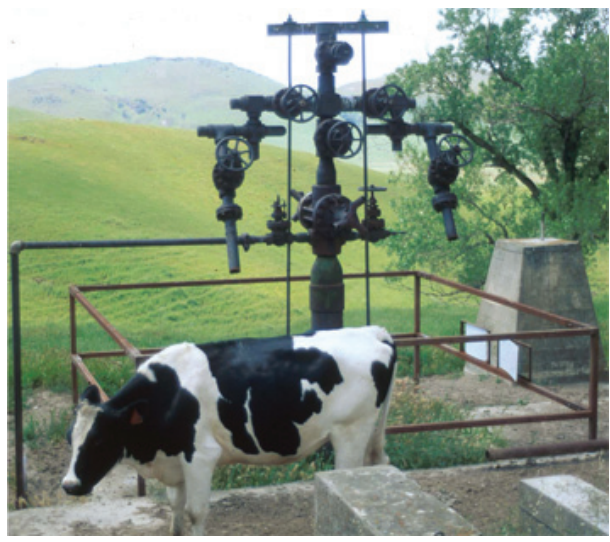

This discovery well at Sutter Buttes still produces gas.

The first commercial natural-gas well in the Sacramento Valley was completed to a depth of 2,727 feet in the southwestern moat of the Sutter Buttes in early 1933. This "discovery well" flowed at 3.4 million cubic feet of gas per day and still produces today, along with many other modern wells. Gas from the wells is collected into pipelines and distributed throughout northern California.

trend, which includes the Berkeley Hills volcanics, the Sonoma Volcanics, and the Clear Lake Volcanics (the youngest of these, with eruptions from 2.1 million years to 10,000 years ago). The Sutter Buttes do not fall on the geographic trend of either the Cascades or the Coast Range. However, the composition, texture, and age of the volcanic rocks suggest that the magmas that formed the Buttes are most likely part of the magmatic system of the Coast Range volcanoes.

But why did eruptions occur at this isolated location in the middle of the Sacramento Valley, far from other volcanoes? Geophysical studies have revealed a prominent northsouth linear "ridge" that has anomalously high magnetism and gravity deep beneath the Sacramento Valley and directly under the Sutter Buttes. These geophysical features may be the expression of a buried, inactive fault that separates granitic and metamorphic rocks of the Sierra Nevada to the east from oceanic rocks of the Coast Range to the west. Additional faults intersect this deep crustal fault to provide possible conduits for

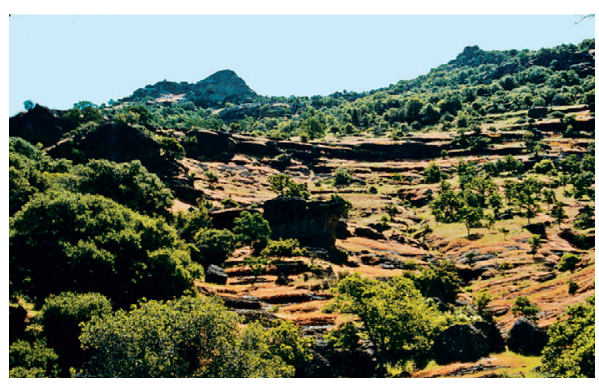

Within the castellated core, layered lake-bed deposits, more than 1,000 feet thick, attest to the former existence of a lake in the center of Sutter Buttes.
Sutter Buttes magmas to rise to the surface. The Sutter Buttes contain the only lavas to erupt at the surface in the Great Valley, but rhyolites similar to those at the Buttes are found in the subsurface just to the west, along the Willows Fault.

The Sutter Buttes stand as a remarkable geographic and geologic feature of California's Great Valley, and they remain a subject of scientific interest and research. One curious feature is the presence at the surface in the castellated core of a huge block, one-quarter mile across, of crystalline rock (Cretaceous granite) characteristic of the Sierran basement. How was this block carried upward to the surface? Or is it perhaps the tip of an upfaulted sliver of the basement deep below? This is one of many puzzles remaining for geologists to solve in future studies.

\section{Selected References}

Cady, J., 1975, Magnetic and gravity anomalies in the Great Valley and western Sierra Nevada metamorphic belt, California: Geological Society of America Special Paper 168, $56 \mathrm{p}$.

Dana, J.D., 1849, Notes on Upper California: American Journal of Science, Article XXV, series 2, v. 7, p. 247-264.

Dickinson, W.R., 1997, Tectonic implications of Cenozoic volcanism in coastal California: Geological Society of America Bulletin, v. 109, no. 8, p. 936-954.

Hausback, B.P., and Nilsen, T.H., 1999, Sutter Buttes, in Wagner, D.L., and Graham, S.A., eds., Geologic field trips in northern California: California Division of Mines and Geology Special Publication 119, p. 246-254.
Thamer, D.H., 1961, Marysville Buttes, in Garrison, L.E., ed., Annual field trip, eastcentral Sacramento Valley-Marysville (Sutter) Buttes-Chico Creek-Oroville: Geological Society of Sacramento, p. 36-41, map scale 1:48,000.

Williams, H., 1929, Geology of the Marysville Buttes, California: University of California Publications in Geological Sciences, v. 18, p. 103-221.

Williams, H., and Curtis, G.H., 1977, The Sutter Buttes of California; a study of PlioPleistocene volcanism: Berkeley, University of California Press, 56 p.

\section{Brian P. Hausback', L.J. Patrick Muffler ${ }^{2}$ and Michael A. Clynne ${ }^{2}$ \\ Edited by Peter H. Stauffer Graphic design by Judy Weathers}

'California State University, Sacramento ${ }^{2}$ U.S. Geological Survey, Menlo Park, Calif.

\section{COOPERATING ORGANIZATION}

Middle Mountain Foundation-The Sutter Buttes Regional Land Trust

For more information contact: Middle Mountain Foundation P.O. Box 3359

Yuba City, CA 95992-3359 (530) 755-3568

http://middlemountain.org, middlemountain@yahoo.com

For hike reservations, contact (530) 671-6116 or

mmfhikes@yahoo.com 